\title{
Women Demeanor at Warfare: Issues, Efficacy and Prospects
}

\author{
Miss. Sneha Kulkarni \\ Assistant Professor \\ Department of Defence and Strategic Studies \\ Bhonsala Military College, Rambhoomi \\ Nashik - 422005, Maharashtra, India.
}

\begin{abstract}
Multiformity in the Armed Forces is a multiform subject, both in terms of vision and in terms of its more pragmatic, administrative meaning. It elaborates one of the utmost symbolic yet critical provocations for human resource management, especially regarding women recruits, that military leaders of Armed Forces have faced over the past few decades. Preeminent diversity in recruitment, reinforcement and services has challenged long established institutional norms, values, beliefs and attitudes in Armed Forces. Utilization of Women under human resource philosophies, policies, programs and practices have been adapted and revised. These revolutionary changes are accumulating evidence of the progress of Women in Military, which has been made in inspecting and responding diversity in the Armed Forces, along with the problems that remain unresolved; mainly focusing on complete synthesis of Women in Armed Forces, which seen as the most problematic; as many nations have yet to resolve genderrelated issues. These forethoughts apply to numerous differences, which are essential to discuss, for enhancing efficacy of Women at War in general and Armed Forces in specific mannerism. The paramount target of this paper is young scholars having desire to join Indian Armed Forces; however authors with all level of proficiency may find useful intellection in the paper.
\end{abstract}

Keywords: Women, Warfare, Armed Forces, Ethics, Efficacy, Human Resource Management, Philosophy

\section{GENESIS OF DEVELOPING ROLE OF WOMEN AT WAR}

"To Be A Soldier One Needs That Special Gene, That Enables A Person To Jump Into One On One Combat, Something, After All, That Is Unimaginable To Most Of Us."

The society and its ideology is moderating in an expeditiously altering arena; where the separation between Non-Combat and Combat Roles; has become obscure by the concepts of Asymmetrical Threat in the context of Modem Warfare. Given this uncertain world scenario, the circumspect for not allowing Women to voluntarily serve in Combat Roles; is no longer determinative; because it is positioned on the biased conclusions and false conjectures of those; who refuse to accept that men and women are equal. Inspite of it is clear that, many women have neither the ability, nor the desire to serve in combat roles, "If Women Have What It Takes And A Desire To Serve, Why Not Let Them?" With the virtuous training and the support from authorities of the Armed Forces at all levels, there is no reason not to employ qualified Women Soldiers in Combat Roles and Warfare. The Armed Forces of various NationStates has faced many convokes to contest over the past few years, and the commissioning of Women in Warfare, if ever approved, will be no different. Along with previous challenges, the countries with a vision of upgrading Armed Forces will expect its Superiors and Leaders to respect its foundation by being Mentors; knowing what to do and doing what is right; with Women at Combat Roles. ${ }^{\mathrm{i}}$ 
With retrospections of contemporary course of time, the paradigm shift is Women have joined the all manner of ranks of the Armed Forces in most Western nations and now in developing Nation-States too. At the same time, elementary disapproval and defiance appear to have been defeated; as there is still debate over the proficiency of employing Women in some and specific occupations, roles and areas of expertise in Armed Forces. Many stagnant nations do not allow Women to serve in Combat Roles, specifically in the course of Warfare and this thought highlights some of the core concerns, some edging on myths regarding the participation of Women in the Armed Forces and distinctively in Warfare; thereby intended to add some clarification, to what has become a continued debate. The context of this debate is the general experience of the nation-states in expanding the portrayal and performance of Women in their military units. The fundamental impediment for Women in participating utterly in the Combat and Non-Combat Roles of Armed Forces today, has little to do with their "physical and mental abilities", but in a certain degree revolves around "social and cultural issues" characterizing a "Warrior" frame of reference; which is considered to be masculine in natural appearance. In identifying those characteristics and abilities that are becoming increasingly necessary within a Contemporary Armed Forces, it is imperative to discuss the strategic importance of shifting the point of convergence to relevant delving to ensure that credible information informs decision making, with respect to the personification of Women in the Warfare peculiarly.ii

Discrepancies of developing significance in the prospects of Role of Women in Armed Forces include those of Age, Gender, Sexual Orientation, Family Status, Disability Status, Language, Race, National or Ethnic Origin, and Religion. Some are biologically determined aspects like Skin Color, Sex, etc. However in reality all of the differences that are important to the services like Military, the Ethic and Habits, Leadership Capability, Preferences for certain type of work, Intellectual Orientation, etc. which can be developed through Education, Training, and other forms of training, Socialization, Experience and Ethical Molding. Furthermore, there is such spacious exception within apparently homogeneous groups that a general impression or stereotype of a group tells us very little about any given individual. The same holds for generalizations from an individual to a group. .ii

\section{INCARNATION OF WOMEN PERSONIFICATION AT WARFARE SYSTEMS}

"A Nation's Army Is As Good Or Bad As Its Officer's Corps."

Since the mid 1970s into the early 1980s, societal and developmental experts began to scientifically address, arguments relating to the impact of women on previously all completemale Military Units of Armed Forces. Corresponding research acquainted both; First, policy decisions to widen the role of women and Second, to undertake research in the area of warfare related employment for women. A present day analysts of worldwide experience share their thoughts as, "The degree to which mixed gender integration has occurred in the Armed Forces, has been significantly over stated for the warfare. Once a woman enrolls in the warfare, the barriers become primarily cultural and social."

India is one of an increasing number of nations, which actually employ women in the combat arms, since many other allied nations have removed limitations on the role of women in their Armed Forces. However, at some extent, exclusion of women from the course of war remains in place in Australia, France, Turkey, the U.K., and the U.S. While New Zealand currently has a combat exclusion for noncommissioned members, it is implementing a multi-phased integration program with a goal of integration into all roles. Also, there are a number of cases where general warfare exclusions do not exist, but where women are excluded from specialized "Elite units". For example, Ireland does not permit women to serve in the AntiTerrorist Army Ranger Wing. Similarly, women have not served in so called "Assaulter" roles in 
Canada's Elite Anti-Terrorist Unit and Joint Task Force (JTF). Although women are not formally excluded from such roles; the physical standards have been set so high that very few women can be expected to meet them or if they do, to sustain the proximate training process, which functions to further "Weed Out" candidates in general. The question here arises that, whether the standards applied reflect the actual requirement. Greece, the Netherlands, Portugal and Turkey have exclusions for women from submarine or other naval services. ${ }^{\text {iv } v}$

Comprehensively, it is seen that, numerous factors can affect the participation rates of women and men in the Armed Forces, in addition to government mandated roles, ethos, ethics, internal values and norms of warfare. Nonetheless, the question is, seeming over emphasis on a "Warrior Ethics", which is centralized predominantly on Combat Operations and War Fighting, to the prohibition of Other Military Operations and Roles; that is Peace Support, Humanitarian and Domestic Support etc. in an organization of Armed Forces in post modern society. The signification of a primary focus on the "Warrior Framework" and women's participation in the warfare are needed to be considered in deliberate thoughtful and applicatory practices.

\section{SYNTHESIS OF THE WARRIOR SPECTRUM OF WOMEN}

"The Moral And Ethical Value System In The Armed Forces Is Not An Abstract Concept. In Fact, It Is The Very Foundation, Upon Which, The Entire Edifice Of The Service Organization Has Been Built. By Virtue Of A Strong Moral And Ethical Value System, The Armed Forces Are Held In High Esteem, By The Citizens Of The Country." vi

Voluminous discourse have been fired up on the role of women in the Armed Forces up to the present time; and most precisely in relation to the ability of Women to adapt to and perform warfare roles; has been actively motivated by Socio-Cultural panorama, streaming from an exclusively Male-Oriented Warrior Framework and to a certain degree beliefs underlying it. ${ }^{\text {vii }}$ By the same token; till time, much of the social and behavioral systematic empirical evidences have been downplayed or ignored in favor of anecdotal evidence, personal opinion and/or uninformed conjecture. However, fundamental questions have been voiced, regarding expansion of role of women, which call for responses, planted on the evidence available today. ${ }^{\text {viii }}$ Stated quite succinctly, in a United States Heritage Foundation article, below are five such questions, which permit us to address issues revolving around; First, the physical and mental suitability of women for Warfare Operational Roles; Second, the impact of women on group cohesion and effectiveness and Third, public and personal attitudes toward women in Armed Forces.

These are:

1. Are women physically suited to the rigors of ground combat?

2. What are the potential consequences of women and men operating in intimate proximity away from home for extended periods of time?

3. What has been the experience of nations that have men and women in mixed combat units?

4. How do women serving in the Armed Forces feel about being assigned to combat units?

5. How will bearing and raising children affect a woman's readiness to deploy on short notice, as is frequently required of military units?

PRODIGIOUS GRAVITY OF ROLE OF WOMEN AS WARRIOR

"Being A Soldier Requires More Than Courage. It Is Sacrificing Yourself For Something Greater Than Yourself." 
The utmost significant pre-requisite for warfare, is physical fitness, which includes aerobic conditioning, strength and endurance, occupying the major part in Armed Forces. Reasonably, more than any other discourse, this has been used most frequently to pick an argument, for the exclusion of women from warfare and combat operations. Recent studies have underlined a new light on this matter and it begins with reference to an example from outside the Armed Forces Organization.

To be mentioned, United Kingdom (UK) Ministry of Defence concluded that "By using new methods of physical training, Women can be built up to the same levels of physical fitness as men of the same size and build." Further, the U.S. and other Nation-State's Armed Forces recognize differential physical aptitude "by age but not by gender." Therefore, the thought we must have to focus on, why some of the same kind of logic cannot be applied to physical differences between men and women. However, the physical ability criteria for inclusion of women in warfare; appear to be both inconsistent and discriminatory to women, emphasizing male areas of physical competence. ${ }^{\text {ix }}$

In 2002, the UK Ministry of Defence conducted one of the most influential studies in recent years on the comparative physical abilities of women and men. On the basis of this study, the U.K. opted not to employ women in combat roles. The review of over 100 studies showed that women had on average less upper and lower body strength than men and that fewer than one percent of women could match the average man's strength. Additionally, women were less aerobically fit and less able to carry out repetitive lifting and carrying tasks. Hence once again, training was shown to dramatically improvement in performance of women and "Women and men exhibit similar relative gains in strength to resistance training programmes and in some studies, women show a slightly greater gain than men." Furthermore, the same report indicated that aerobic fitness training yielded a greater response among women than men and reduced the aerobic fitness gap between the sexes. As the report points out, this increase may be due to "an initially lower state of training among women on entry in the Armed Forces."x xi This analysis is reinforcing arguments made earlier in connection with the arguments made on unsuitable physical features of women and simultaneously, the impact of physical education requirements in schools and colleges, specially designed for female candidates. ${ }^{\text {xii xiii }}$

Most services and roles in the Armed Forces are not based on kosher standards established to perform the tasks. It follows that, in some instances, not tied to authentic occupational standards, the lower physical performance of women, may resolve into simply be irrelevant. Henceforward, it is essential for various developing and developed Nation-States, to mould the defence strategies and policies of respective Armed Forces, which will include, implement and initiate an ethical framework for women as a human resource for warfare, specially to develop the requirements of physical standards of women, by taking insightful consideration of following points;

1. Identification of the operational requirements of warfare

2. Identification of the physical capability required to complete the operations

3. Developing pragmatic assessment which ensue the capability to complete the operation

4. Structuring parity in standards of the warfare operational tasks

\section{DIORAMA OF NATION-STATES WITH JOINT MEN \& WOMEN WAR OPERATIONAL UNITS}

"Quality Is Job ONE."

Some Nation-States like Russia, Israel, historically, have employed women in operational units at times of war and then either disbanded such units shortly after the war or seized to utilizing women as human resource in more traditional roles of Armed Forces. This has been taken by 
some as an indicator, of the failure of women in the combat roles of war courses. Be that as it may, such decisions may be guided more by political or cultural or religious influences, than by strategically \& tactically designed organizational considerations of Armed Forces.

In recent years, court decisions and public pressures have forced to Armed Forces of various Nation-States, opening more roles to women. For example, Germany now permits women in war operational units; thusly joining Canada, Denmark, Norway, Spain, and Sweden in opening up all warfare positions to women. Some have argued that these countries do not represent good examples of possible dangers of mixed gender war operational units; because they have not played leading roles in recent years in waging war or sustaining war like situations. As a UK Ministry of Defence report put it in 2002, "Those nations that optimize their forces for highintensity warfare, which see war fighting rather than Operations Other Than War (OOTW) or peacekeeping as their purpose, appear most cautious about deploying women in combat units." xiv xv This postulate, those Nation-States that may participate more frequently in peace support and humanitarian operations never go to war and that their militaries do not view themselves as warfare capable forces. This is certainly not the case for many of the Nation-States that allow women in war operational units. Also, peace support operations undertaken since the end of the Cold War often have had operation related requirements that closely resembled war fighting. Many Nation-States have now had at least some experience of mixed gender war operation units, with little evidence of negative impacts on effectiveness or cohesion or readiness. Armed Forces fears about mistreatment of Women prisoners of war have been realized.

\section{EFFICACY OF WOMEN EMPLOYMENT AT WARFARE AS WARRIOR}

"What Is The Next Thing You Need For Leadership? It Is The Ability To Make Up Your Mind To Make A Decision And Accept Full Responsibility For That Decision." - Sam Manekshaw

Organizational cohesion is seen as an essential element of war operation units. Developing an environment of organizational cohesion takes time. Ethics elaborate that; all members of the unit must share common experiences and build confidence in each other. The fact that women can become pregnant and require time off to give birth and nurse children has been argued as having a potentially negative impact on such cohesion developing endeavors. However, this argument discounts the fact that, extended absences from units can be caused by many reasons, pregnancy being one of the least important.

Women were twice as likely as men to recite family or children as their most important reason for having either no interest in joining the Armed Forces or obligations by other societal means for their joining. Withal, for most parts, those women who do choose to join Armed Forces, are likely to have contemplated family relevant issues and are also making a choice similar to that of men, corresponding to their present as well as future family commitments. Albeit, women in general, still have disproportionate responsibility for raising children, men increasingly share this role; for this reason, exception in one parent situations; the burden of family should be looked upon as a joint responsibility. Determinately, similar to other large scale employers, the Armed Forces have highlighted that morale, motivation and retention of women and men depend on policies that provide greater ability to balance the demands of family and service to the organization. Comprehensively, such policies form parts of the overall human resource support structure, of most contemporary Armed Forces of Nation-States have included. ${ }^{\text {xvi xvii }}$

"Excellence Is Not A Skill, It Is An Attitude." 
Another issue here is; First, whether or not women are interested in being employed in war operation units and roles and Second, the degree to which such is the case and the basis for their views one way or the other. The answer is, expanded exposure for women to Armed Forces and war operation unit services, will no doubt have the influential impact as that of making service positions more appealing and interesting.

Warrior Ethos and the Warrior Ethic have been defined in various ways to convey the central elements and values of the culture, including moral and ethical courage, tactical skills, emotional and physical stamina, loyalty to comrades, and determination to accomplish the mission. ${ }^{\text {xiii }}$ While many analysts would argue that, the Warrior Framework is uniquely being applied to the war operational units and there is an increasing emphasis on "Warrior Like" characteristics, as essential to all Armed Forces. Research over the past decades has established plentiful barriers to the integration of women into various roles in the Armed Forces and Warfare system. ${ }^{\text {xix }}$ xx Suggestible approach is that, Warrior characteristics expressed through the terms as "Warrior Ethos", "Warrior Culture", and "Warrior Spirit"; will progressively dominate the development of policy and doctrine of Warfare and subsequently the Armed Forces. In addition, this changeover will secure legitimacy within organizations of Armed Forces, to identify artistry and attributes other than Traditional Warrior Attributes, which will become more and more significant for the future. Hence, the treatment of women in the Warrior Culture, therefore, appears to be based on assumptions, unrelated to Women's abilities and aptitude to perform in the Warfare and Armed Forces.

PROSPECTS: WOMEN DEMEANOR AS WARRIOR OF FUTURE

"Integrity Is Choosing Your Thoughts And Actions Based On Values Rather Than Personal Gains"

Throughout the time, physical strength and stamina do remain to play a significant role in Soldier Effectiveness in the course of War and Armed Forces. The question remains as; to whether the same physical standards are required to achieve the purpose of avant-garde Armed Forces and war strategies. The traditional arguments of physical and mental suitability of women, for warfare appear to have been productively countered, by growing evidence showing, that many women would be able to participate at the highest levels, comparable to men if given the proper training, orientation and leadership. Nor have the affirmations of a negative percussion of women on organizational cohesion and effectiveness of Armed Forces, been supported by empirical evidences. More than this, even those Nation-States, which have been most vehement in their opposition to women involvement in warfare, have not exempted women from "Near Combat Roles." Elevated worth of technology, rather than vigor, is becoming a signet of modern warfare. The days of mass infantry ground attacks are less extensive, at least for most Armed Forces in various Nation-States.

The emerging warfare roles of peace building and peacekeeping; the Armed Forces have increasingly confronted a large scale mosaic of warfare situations; ranging from conventional warfare to urban terrorism and guerilla skirmishes. The weaponry and skill sets needed to perform the duties of the modern military have changed; suggesting the need to consider a range of psychological, physical and cognitive competencies that go beyond absolute brute strength and vigor. This does not mean that physical fitness, physical conditioning and training are not important, but does underline a thought that, instinctive strength and vigor is not an actual occupational requirement of modern warfare. There are ample of evidences, that the requirements of Warrior Framework are developing dynamically and hence the importance of deriving standards of warfare are based on requirements to actualize the objective of Armed Forces through the prospect of utilizing the efficacy of women warrior ethos and ethics. 
The Armed Forces are inseparable part of the society closely associated with the culture of the polity, bureaucracy, social structure. The Women are base of societal architecture and security concerns. The Armed forces, a framework developed for maintenance of territorial sovereignty, safety, security and good will of the nation, obviously have to consider the inseparable asset of the country, Women as its own part to perform all the essential work devoted to nation. The need is to develop and promote a set of ideas to press the worldwide society and governments to adopt pragmatic and foresighted policies towards the Women to unfold their life style and permit them to perform all credible operations in the al branches of Armed Forces proven by their efficacy. Therefore various aspects of Women and Armed Forces including issues, efficacy and prospects have to be studied, discussed and analyzed for benefit of not only Women and the Forces but also the society to which they belong.

iFor historical data on women's participation in the Canadian labour force and the federal public service in Canada, see Minister of Supply and Services Canada, Beneath the Veneer: The Report of the Task Force on Barriers to Women in the Public Service (Ottawa: Canadian Government Publishing Centre, 1990)

ii N. J. Holden and L. M. Tanner, An Examination of Current Gender Integration Policies and Practices in TTCP Countries (Ottawa: Director Strategic Human Resource Coordination, Personnel Operational Research Team \& Director Military Gender Integration and Employment Equity, ORD Report R2001/01), for a historical overview of women's participation in the militaries of The Technical Cooperation Panel

iii National Defence, Mixed Gender Crewing of Victoria Class Submarines (Ottawa: NDHQ MARGEN 016/01 CMS 021/01, 2001)

iv R. E. Park,Overview of the Social/Behavioural Science Evaluation of the 1979-1985 Canadian Forces Trial Employment of Servicewomen in Non-Traditional Environments and Roles, Research Report 86-2 (Willowdale, ON: Canadian Forces Personnel Applied Research Unit, 1986)

v R. E. Park,Public Opinion and the Placement of Canadian Forces' Servicewomen in Combat, Paper presented at the 20th International Applied Military Psychology Symposium, Brussels, 1984

vi https://www.linkedin.com/pulse/indian-army-moral-ethical-value-systems-dsa-magazine

vii K. D. Davis, Chief Land Staff Gender Integration Study: The Experience of Women Who have Served in the Combat Arms, Sponsor Research Report 98-1 (Ottawa: Personnel Research Team National Defence, 1998)

viii Franklin C. Pinch, Selected Issues and Constraints on Full Gender Integration in Elite Ground Combat Units in Canada (Kingston, ON: FCP Human Resources Consulting, 2002)

ix The Czech Republic, Denmark, Hungary, Netherlands, Norway, Austria and Ireland have women serving in combat arms occupations. See Committee on Women in the NATO Forces, Teambuilding Towards New Challenges, Member nation and Partnership for Peace reports to the Annual Meeting of the Committee of Women in NATO Forces, Brussels, 2002

${ }^{x}$ Committee on Women in the NATO Forces, Teambuilding Towards New Challenges

xi Holden and Tanner, An Examination of Current Gender Integration Policies and Practices in TTCP Countries

xii Committee on Women in the NATO Forces, Teambuilding Towards New Challenges

xiii Ibid

xiv K. D. Davis, The Future of Women in the Canadian Forces: Defining the Strategic Human Resource Challenge, DSHRC Research Note 10/01 (Ottawa: Director of Strategic Human Resources Coordination, National Defence, 2001)

xv John Luddy, “Congress Should Hold Hearings Before Allowing Women in Combat," Heritage Foundation Backgrounder \#230. (Washington: The Heritage Foundation, 1994)

xvi Kim Field and John Nagl, “Combat Roles for Women: A Modest Proposal,” Parameters (Summer 2001)

xvii L. Casey, "Women in Combat": 3. http://www.militarywoman.org/academic.htm

xviii B. Wilson, “Women in Combat: Why not?” http://userpages.aug.com/captbarb/combat.html

xix Field and Nagl, "Combat Roles for Women": 8

xx C. Prandzik, “Runners Life: Want better endurance, be female study suggests," Army Times (13 May 2002 ): 1 